\title{
Ugly and Interested Art. Modernity, Freedom and democratization of taste in F. Schlegel
}

\section{Giorgia Cecchinato}

\section{(2) OpenEdition \\ Journals}

Electronic version

URL: http://journals.openedition.org/ref/756

ISSN: 2258-014X

Publisher

EuroPhilosophie Editions

\section{Electronic reference}

Giorgia Cecchinato, « Ugly and Interested Art. Modernity, Freedom and democratization of taste in F. Schlegel », Revista de Estud(i)os sobre Fichte [Online], 15 | 2017, Online since 01 December 2017 connection on 08 September 2020. URL : http://journals.openedition.org/ref/756

\section{This text was automatically generated on 8 September 2020}

(c) EuroPhilosophie 


\title{
Ugly and Interested Art. Modernity, Freedom and democratization of taste in F. Schlegel
}

\author{
Giorgia Cecchinato
}

1 The German intellectual world at the end of the $18^{\text {th }}$ century was shocked by the French revolution and by Kant's Copernican revolution. It was subsequently driven to question the sense of modernity and the possibilities and instruments for understanding these years of radical changes. The debates in aesthetics were involved in this wider investigation of the sense of modernity. Hence, the old Querelle des anciens et des modernes came back with a new strength. In this context, Schiller's essay "On Naïve and Sentimental Poetry" is particularly relevant ${ }^{1}$. On the one hand, in this essay Schiller recognizes that the naive and natural character of ancient poetry has a fundamental value, as an ideal of spontaneity and completeness. On the other hand, he ascribes a new meaning to the artificial and sentimental character of modern poetry. Modernity is characterized by the birth of consciousness and therefore by the kind of freedom that raises from a non-natural and reflexive approach to life, which did not exist in ancient times. This interpretative scheme was decisive for Hegel and it became crucial for Schlegel too.

2 My aim in the first part of the paper is to describe how Schlegel develops this idea of Schiller's and to show how he, by reflecting on modernity, leaves out the ideal of beauty from aesthetics and develops a wider range of possibilities for what could be recognized as a work of art. In the second part, I will demonstrate that Schlegel goes beyond Schiller's project of an aesthetic education, because his way of thinking about art opens more possibility for dialogue and inclusion than Schiller's model based on beauty. This will allow us to see that Schlegel's romanticism as an aesthetic theory can be very useful and fruitful to us in contemporary era. 


\section{The "interesting" as aesthetic category}

3 In the 1795 essay On the Study of Greek Poetry, Schlegel focuses on the ideal character of ancient poetry, and in this way sheds light on all that was lacking in what was then modern poetry. In later writings, in particular in the Preface to this 1795 essay, the shortcomings of modernity and of modern art do not seem overly negative: on the one hand, antiquity represents the objectivity of artistic ideal, and it is not possible to count on modern readers' possibility of having an objective taste or of being trained to understand objectivity. On the other hand, modern taste is not the result of barbarity, but of the distinctive feature of one's times: individual and autonomous subjectivity. The development of a free subject, no longer regulated by nature, results in the shift from the key role of objectivity and harmony in the ancient aesthetic to the supremacy of the "interesting" in the modern reflection on art. The "interesting" is the only main guiding idea that connects the various different tendencies of modern art. The panorama of arts, and generally the modern era seems to be dominated by chaos and anarchy. The artist seems to be apart from the whole of the Bildung, as if everyone acts according their individualistic urges, without care for the others: "as a matter of fact every artist exists for itself (fuer sich); he is an isolated egoist" 2 . Even the investigation about an objective law of beauty generated a multiplicity of opinions and theories, whose unity can only be found in the implicit doubt about the possibility of an objective and universal aesthetic law $^{3}$. In every sphere chaos prevails: in politics as a consequence of the supremacy of the Third State after the French Revolution and the tension of crown of Europe, in the sciences and arts because there is no more boundary between art and science, and among arts.

"The boundary between science and art, between true and beautiful are so confused that even the conviction about their immutability starts to sway everywhere.

Philosophy poeticizes, poetry "philosophies"'".

With regard to such chaos, Schlegel does not give up the possibility of finding a common plane for modern culture. Rather he affirms that this absence of harmony and order constitutes the central idea of all modern cultural experiences. In this way it is possible to consider the European modern culture as a whole, a totality. In this whole the art is characterized by the prevalence of the individual and interesting, that is what the spectator wants: no more the beautiful, but something new, different, something that stimulates reflection. In order to understand this peculiarity of modern culture, we must consider the definition of Bildung as interaction between nature and reason. In the ancient world nature is not only the moving force, but the main guide of human production too; in the modern world production, culture in general, is guided by the understanding. In this case the human act and deliberation are more important than the natural element, and freedom dominates nature. The consequences of this change of balances are both positive and negative. On one hand when reason dominates it seems possible to find a legislation that drives the cultural development to the ends determined by reason. That's why modern people are searching for law and they find it in the normative character of the ancient art. On the other hand, when the imitation of the ancients becomes no more satisfactory for the understanding, the free will, emancipated from every kind of law, acts in order to produce autonomously something original. Understanding and freedom are very close to each other, but freedom without a law easily becomes free will (arbitrium); in this case it produces only nostalgia and pessimistic works. Modern culture is an artificial one, and it is searching for an ideal, 
for a law, but doesn't find one which is really normative. Consequently every artist plays with different elements, as if he were a chemist he separates and unifies natural elements in order to show his capacity to impose his will on matter, on nature ${ }^{5}$. It is good to remember that Schlegel in a fragment written in 1797, affirms that the modern era is a chemical one ${ }^{6}$, and about ten years later Goethe in his novel Elective affinities describes the relationships of two couples with a chemical metaphor, and in this way deals with the problem of the contrast between nature and free will.

In the modern chemical era the artist does not aim at the creation of the beautiful, but he tries to imprint his own subjectivity in original and interesting works. A work of art is successful when it stimulates the curiosity of the spectator and piques his interest, but a work that is original in the moment $\mathrm{t} 1$, can lose its stimulating character in the moment $\mathrm{t} 2$ because the flow of time normalizes it. Every interesting work of art can be made outdated by another one that is more interesting or interesting in another way. In the ancient world the artist with a beautiful work reached the maximum of an ideal and every beautiful work in itself represents and embodies a maximum. In the modern world that is no longer possible, there is no more a maximum that each work in itself embodies, the modern artist is searching for a maximum absolute, but, as we have seen, interesting can not be absolute. This fact generated a "paradoxical situation"':

"The more one distances oneself from pure truth, the more one has partial opinions about the truth and even more bigger is the whole of that what was the original, and even more rare and pure the new originality"s

6 There is no work of art that is interesting in the absolute sense because there is no aesthetical law, canon or purposiveness (Zweckmessigkeit). Every work of art follows other works of art, and obscures their originality. At the same time that work will be obscured by a successive one more original and interesting. Every creation depends on the previous one because it must exceed the grade of the previous one; in this sense it belongs to the history of art. Actually that is not progress or an improvement in the sense of the Enlightenment (Aufklaerung); instead in this dynamic process the originality is always normalized and a new creation must every time invade the plane of the ordinary world. In this process there is no progress, but a continuous break, a breakdown of the world of art and its reconstitution thanks to other, more original works of art.

\section{Interesting and critical activity}

7 In the first part of this paper, I tried to delineate the theory of the interesting in Schlegel's early work, On the Study of Greek Poetry. Now I'd like to highlight the most meaningful aspects of his aesthetic theory with respect to, on the one hand, the aesthetics of the 18th century, in particular Kant and Schiller; and on the other hand with respect to some aspects of the contemporary aesthetics 9

8 The introduction of the category of "interesting" explains and justifies the exclusion of the beauty from the art world and moreover opens the doors of the art world to the ugly and to the disgusting in a way that is very close to what Arthur Danto made two centuries after Schlegel. Finally for Schlegel, as for Danto, everything can be $\operatorname{art}^{10}$. Furthermore the German philosopher delineates exactly what the art world is and what are its boundaries: that is the set (whole thing) of objects that are produced by the free 
will, that manifests human freedom and intelligence and that raises interest and piques reflection.

At the same time Schlegel affirms the flexibility of the art world, considering that it is, as the modern era, dominated by chaos, that means that science can become art and art can make philosophy ${ }^{11}$.

It is possible to better understand the way in which the artist and her public relate to the precariousness and to the subjective and temporary nature of the works of art by considering Schlegel's successive reflections on the critical character of the creative activity in both the production and reception of art. Schlegel distances himself from the dogmatism of Winckelmann and Gottsched because for them works of art must be judged on the basis of objective norms. But Schlegel distances himself from Kant too, because he is not in accordance with the thesis of judgment intended as individuation of the universal in the particular, even if, as in Kant, the universal is not a priori given and must be found. In other words, the critic is not an instrument to eliminate the particular and the contingent, the relative and the individual, as if these were only a form of illusion or appearance that hides something universal and objective. The critical activity is rather the medium with which every individual and incomplete artwork refers to the absolute and infinite idea of the art. The critic does not search for the accordance between the particular and the universal, but instead it looks for the valorization of the particular character of the work and its peculiarities. Consequently it is not possible to achieve a definitive judgment on a work of art, but every judgment, every critic contributes to its completion and save it from its limits and relative characters, as W. Benjamin highlighted. The critical activity is a reflection on the condition of possibility of a work and of a judgment about a work, and finally is a reflection on the possibility of such a critical activity. That means at least that critic is always aware of its temporary and provisional character and moreover it is aware of the precariousness of the art. Although the critic must be aware of the fact that every judgment on something that arouses an interest can not have can not have a neutral character, that is can not be pronunciated without the intervention of desire and previous knowledge, that is: can not have disinterested character in the sense of Kant's Critique of judgment. Instead, every critical judgment, for Schlegel, involves the entire individuality, the one of the critic and the one of the artist.

11 The critical activity in Schlegel's sense, is not a Kantian judgment of taste, which pretends that the one who judges puts aside his particularity to reach a universal, neutral point of view. In the modern era the universality is lost, as the law of beauty. Only the critic can save modernity from relativism, because the critic consists in the awareness of the relative character of every judgment and in the awareness of the presence of a more or less implicit interest.

This way of understanding critical activity in art can have meaningful implications in the political praxis ${ }^{12}$. As we know the romantic Philosophers together with Schelling and Schiller considered art as the most effective activity in order to express and to understand the human being. Hegel strongly critiques them because he does not agree with the theory that art and philosophy of art can help understand and solve the problems of modernity.

13 In his epistolary work, "Letters on the aesthetic education", Schiller affirm the possibility of ennobling the humanity trough art, and in this way of contributing to a political renovation. The experience of the beauty becomes a sort of ground zero: all 
the strivings, rational and sensible in the experience of beauty are still. The particular ends and cognitions are annihilated and in this way the space for the play of the beauty is opened. But beauty doesn't teach us anything, it does not command anything, it only makes an open space for all types of dialogue. Schiller is inspired by the Kantian theory of the sensus communis as an ideal society of judgers, in which every one can participate in a dialogue from a neutral, universal point of view.

Whereas Kant with the theory of common sense refers only to an ideal justificatory ground for the judgment of taste, Schiller transforms this theory in a political proposal in order to educate the sensibility and contributes to a moral (that is freel) development of the political community. But he admits the utopian character of this kind of education and implies the difficulty of such a pure and disinterested experience. In the latest letter he ask "Where can we find such an aesthetic State?" and he answers as follows: "in the hearts of the select few members of a small circle"13.

In more than on one occasion Schlegel accuses Schiller that he did not really "digest" Kantian Philosphy. In fact the ahistorical and disinterested character of the judgment of beauty that we find in Kant, becomes in Schiller the key for making the political community more just and free.

Schlegel's proposal seems certainly more realistic and appropriate: he affirms that art as well as other products of human reason, such as the State (the Republic) and philosophical systems are based on artificiality (Kunstlichkeit) and temporary nature with which one must deal, because one can not annihilate or easily overlook them. The right attitude is the critical one: it is important to be aware of the artificial, conditional, individual, and interested character, which is the product of the understanding and of our judgments; in this way one can be open to the future and able to respect individuality of others and to improve one's own.

\section{Bibliography}

Beckenkamp J., (2004). Entre Kant e Hegel. Porto Alegre: EdiPUCRS.

Behler E., (1993). German Romantic Literary Theory. Cambridge: Cambridge University Press.

Bernstein J.M., (2004). "Poesy and the arbitrariness od the sign. Notes for a critique of Jena romanticism", in: Nikolas Kompridis (ed. by), Philosophical Romanticism, New York: Routledge, 143-173.

Danto A.C., (1981). The Transfiguration of the Commonplace. A Philosophy of art. Ambridge MA, London: Harvard University Press.

Danto A.C., (1997). After the End of Art. Contemporary art and the pale of history. Princeton: Princeton University Press.

Frischmann B., (2001. Friedrich Schlegels frühromantische Kritikkonzeption und ihre

Potenzierung zur "Kritik der Kritik", in: Archiv für Begriffsgeschichte 43, 83-111.

Kant I., Kritik der Urteilskraft [1790], Gesammelte Schriften, Bd. V, Königlich Preußlichen Akademie der Wissenschaften (Hrsg.), Georg Reimer, Berlin 1910 p. 165-485;

Schiller F., Über die ästhetische Erziehung des Menschen in einer Reihe von Briefen, in: Philosophische Schriften. Erster Teil. Unter Mitw. von Helmut Koopmann hrsg. von Benno 
von Wiese. 1962. Unveränderter Nachdr. 2001. Nationalausgabe, Bd. 20, Weimar: Verlag Hermann Böhlaus Nachfolger Weimar $1943 \mathrm{ff}$.

Schlegel Fr., Kritische Friedrich-Schlegel-Ausgabe, Bd. XXIII, Schöningh-Thomas, Paderborn Zürich 1979.

Id., Über das Studium der Griechischen Poesie [1795-1796], KFSA I, p. 217-368.

Valpione G., (2014) La frammentazione dell'ordine. Comunità e critica in Friedrich Schlegel. [Tesi di dottorato]. http://paduaresearch.cab.unipd.it/6993/

\section{NOTES}

1. On the relavance of Schiller's essay for F.Schlegel see Beckenkamp 2004: 161-184.

2. KFSA I, 239.

3. KFSA I, 218-220.

4. KFSA I, 219.

5. On this aspect see Behler: 1993, 95-110.

6. Athenaeum Fragment 426 KFSA II, 249.

7. Valpione: $2014,54$.

8. KFSA II, 239, quoted by Valpoine: 2014 too, see p. 54.

9. Bernstein, 2004 interprets the consequences of Schlegel's aesthetical thought as analogous to the theory of the death of art that we find in G.W.F. Hegel and A.C. Danto.

10. Danto: 1997, p. 44.

11. Danto aims precisely at a definition of art that is sufficiently pluralist to accommodate all possibilities, see Danto: 1981.

12. This aspect is explored by Valpione: 2014, 103-139.

13. Schiller: 2016, letter XXVII.

\section{ABSTRACTS}

The aim of this paper is to describe how F. Schlegel develops F. Schiller's conception of the modern art and to show how he, by reflecting on modernity, leaves out the ideal of beauty from aesthetics and develops a wider range of possibilities for what could be recognized as a work of art. Schlegel goes beyond Schiller's project of an aesthetic education, because his way of thinking about art opens more possibility for dialogue and inclusion than Schiller's model based on beauty. This will allow us to see that Schlegel's romanticism as an aesthetic theory can be very useful and fruitful to us in contemporary era. 
INDEX

Keywords: modern art, Schlegel, interesting, beauty, poetry

\section{AUTHOR}

\section{GIORGIA CECCHINATO}

Universidade Federal de Minas Gerais 